\title{
Hadím jedem indukovaná koagulopatie - editorial
}

\author{
Jiří Valenta \\ Toxinologické centrum, Klinika anesteziologie, resuscitace a intenzivní medicíny 1. LF UK a VFN v Praze \\ Komentáŕ k | Editorial on \\ Nehaj F et al. Trimeresurus albolabris - štrkáčovec bieloústy, hlásenie uhryznutia. Vnitř Lék \\ 2018; 64(7-8): 802-806.
}

S povděkem prijímám nabídku redakce časopisu Vnitřní lékařství reagovat na kazuistiku předloženou slovenskými kolegy, a to předně z důvodů možnosti ozřejmit širší lékařské veřejnosti patofyziologické minimum hemokoagulačních selhání po uštknutí exotickými hady a logistickou osu řešení obdobných vzácných intoxikací.

Hadím jedem indukovaná koagulopatie (Venom-Induced Consumption Coagulopathy - VICC) je vzhledem k chovaným druhům hadů v našich podmínkách nejčastějším systémovým projevem intoxikace po uštknutí exotickými jedovatými hady. Od roku 1999 bylo v Toxikologickém centru (TC) Kliniky anesteziologie, resuscitace a intenzivní medicíny 1. LF UK a VFN v Praze konzultováno nebo hospitalizováno 107 pacientů uštknutí exotickým jedovatými hady s 36 projevy systémové intoxikace, z toho 25 pacientů s projevy VICC. Terapie antisérem byla provedena u 5 z nich. Vhodné je také připomenout, že ne každé uštknutí hadem je spojeno s intoxikaci. Ve shodě s literárními údaji a dle analýzy TC se u téměř 20 \% případů jedná pouze o tzv. dry-bite; had po zákusu nevypustí do rány jed.

Popsaný případ je ilustrativní ukázkou klasického průběhu VICC po uštknutí hadem (chřestýšovec běloretý Trimeresurus albolabris, recentně Cryptelytrops albolabris), který sice složením a množstvím svého jedu není řazen mezi vysoce nebezpečné, nicméně i v těchto případech dochází k závažné poruše hemostázy. Ta může ústit až do hemoragií včetně orgánových, ohrožujících pacienta na životě, a má v zemích výskytu i nezanedbatelnou mortalitu.

Hemokoagulačně aktivní složky se vyskytují u většiny zmijovitých hadů (Viperidae), kromě zmijí evropských, a to jak u chřestýšů (Crotalinae), tak u zmijí (Viperinae). Jedy zmijovitých hadů jsou enzymatického typu, tj. převážná většina aktivních složek je tvořena toxickými enzymy. Tyto součásti jedu ovlivňují mj. v různé intenzitě všechny základní složky hemokoagulačního systému - plazmatický koagulační systém (PKS), krevní destičky i endotel. Navíc obsahují v různé intenzitě tzv. hemoraginy, složky způsobující dezintegraci a poškození cévní tkáně, endotelu i subendotelia, projevující se klinicky především v kapilární oblasti.

Složky jedu ovlivňují hemokoagulaci ve smyslu pozitivním i negativním. Prokoagulačně působí na PKS předně enzymy konvertující fibrinogen na fibrin přímým odštěpením fibrinopeptidů (trombin-like fibrinogen konverzní enzymy) a složky aktivující protrombin nebo jej měnící na aktivní, komplexem antitrombin/heparin neinhibovatelné izoenzymy (meizotrombin), a dále aktivátory FV, FIX, FX. Antikoagulačně se, krom nevýznamné aktivace proteinu $C$, uplatňuje především fibrino(geno)lýza, a to jak primární, tak daná zvýšením plazminové aktivity. Výsledkem je defibrinace s vysokou tvorbou fibrin degradačních produktů (FDP), většinou včetně $D$-dimerů (D-dim) [1-3].

Krevní destičky mohou být složkami jedu aktivovány nebo inhibovány. $V$ prípadě inhibice se většinou, zvláště $v$ počátečních fázích intoxikace, neprojevuje jejich deficit [1,2].

Endotel a subendotelium jsou atakovány především destrukčním působením hemoraginů, ale i působením dalších složek jedu.

Výsledkem je komplexní a složitá porucha hemostázy konzumpčního typu, nejvhodněji označovaná jako VICC $[4,5]$. Mnohdy bývá zjednodušeně slučována s diseminovanou intravaskulární koagulací (Disseminated Intravascular Coagulation - DIC), nicméně se od klasické DIC liší v řadě ohledů. Předně, závažná aktivace PKS způsobená trombinovými izoenzymy není inhibovatelná komplexem AT/heparin, stejně jako působení tzv. trombin-like fibrinogen konverzních enzymů. Vzniklá hypofibrinogenemie není pouze konzumpčního typu, ale je zčásti způsobena i primární fibrinogenolýzou. Krevní destičky nebývají při procesu konverze fibrinogenu (FBG) aktivovány tak, jak je tomu při generalizaci trombinové aktivity u DIC. Navíc, jejich agregabilita bývá složkami jedu inhibována. Totéž platí i o aktivitě AT, který se ve většině případů inhibice trombinové aktivity nemůže účastnit.

Rozvoj VICC je oproti jiným systémovým projevům intoxikace hadími jedy relativně pomalý. $\mathrm{V}$ laboratorním nálezu se může projevit až s odstupem několika hodin. První známkou rozvoje koagulační poruchy je mnohdy nevýrazný pokles hladiny FBG. Citlivějším časným markerem bývají vysoké hodnoty $D$-dim, zřetelné ještě před významnějším poklesem FBG. Koagulační porucha se dále laboratorně vyvíjí prodlužováním koagulačních časů, protrombinového času (Prothrombin Time - PT) a aktivo- 
vaného parciálního tromboplastinového času (Activated Parcial Tromboplastine Time - APTT) a je samozřejmě prokazatelná i tromboelastografí. Porucha, pokud se rozvine, kulminuje laboratorně v rádu až desítek hodin hypofibrinogenemií až afibrinogenemií s prodlouženými nebo neměřitelnými koagulačními časy. Při tomto nálezu mohou být počty krevních destiček a aktivity AT v normě, nebo pouze lehce sniženy.

Klinicky se defibrinace $v$ časných stadiích nemusí nutně projevit zvýšenou krvácivostí intaktních tkání, nicméně trvání poruchy je život ohrožující stav s hrozícími závažnými orgánovými hemoragiemi $[1,6]$. Perzistující VICC predisponuje i ke vzniku oligoanurického seIhání ledvin, ev. v těžkých prípadech i multiorgánového selhání, mj. za spoluúčasti tvorby mikotrotrombóz.

Hlavní roli ve finální terapii VICC hraje přislušné, většinou polyvalentní antisérum. $K$ neutralizaci jedu je mnohdy nutné podat jej ve vyšších, nebo opakovaných dávkách pro nízkou antigenitu některých koagulaci ovlivňujících složek.

Samotná substituční léčba FBG bez neutralizace jedu je téměř neúčinná a není doporučována. Podaný FBG je nadále konzumován a destruován. Výsledkem je pouze zvyšování hladin FDP, ev. zvýšení tvorby (mikro)trombóz, přičemž hypofibrinogenemie nebývá zásadně ovlivněna [2].

Nicméně, přetrvávající afibrinogenemie zvyšuje riziko závažných hemoragií. Jistou alternativní možností v krajní situaci a při klinických projevech krvácení může být podání čerstvě zmražené plazmy (ČMP), obsahující kromě FBG další koagulační a inhibiční složky ve fyziologickém poměru. Touto substituční terapií $s$ velmi omezeným a krátkodobým účinem je však možno překlenout čas do doby neutralizace jedu antisérem $[2,7]$.

Heparin v akutní fázi intoxikace neovlivní pozitivně její průběh a pro nebezpečí zvýšené krvácivosti není jeho podání doporučováno [2].

Toxikologické centrum bylo ustaveno $v$ roce 1993 se schválením MZ ČR jako konzultační a léčebné místo $\mathrm{k}$ řešení př́padů intoxikace živočišnými toxiny, především po uštknutí jedovatými hady.

\section{Náplň činnosti TC pro ČR:}

- stanovit konzultačně pravděpodobnost vývoje intoxikace po zranění jedovatým živočichem

- doporučit primárnímu zdravotnickému zařízení (ZZ) vhodná vyšetření ke zjištění prítomnosti systémového postižení a prípadné nutné symptomatické zajištění pacienta

- v prípadě intoxikace hospitalizovat pacienta a zajistit jeho terapii včetně léčby antisérem z depa VFN nebo jeho urgentním dovozem, je-li dostupné v EU

$\checkmark$ prípadě potřeby TC provádí konzultace i pro $Z Z$ ve Slovenské republice. Je-li indikována léčba antisérem, doporučí možná místa jeho získání. Omezené spektrum antisér je sice uloženo na Toxikologickém infor- mačním středisku (TIS) Kliniky pracovního lékařství 1. LF UK a VFN v Praze, ta však nemohou být do SR poskytnuta pro absenci dohody, jejíž vznik však může být slovenskou stranou v budoucnu iniciován.

Prakticky všechna potřebná antiséra je možno získat z jiných evropských center (SRN, Švédsko, Švýcarsko, Velká Británie), nejčastěji via Giftnotruf Muenchen, Klinikum Rechts der Isar, http://www.toxinfo.med.tum.de/. Většina v Evropě dostupných antisér má však prošlou exspirační lhůtu. Tento fakt, spolu s legislativní restrikcí možnosti dovozu antisér do ČR, staví budoucnost léčby "lege artis" intoxikací jedem exotických hadů do nejisté polohy.

\section{Logistická osa řešení stavů po uštknutí jedovatým hadem}

- postižený navštíví ZZ nebo kontaktuje Zdravotnickou záchrannou službu (ZZS)

- ZZ (ZZS) konzultuje situaci stejně jako u jiných méně obvyklých intoxikací s TIS (+420 224919 293, +420 224915 402)neboprímosTC (+420 224963 355); předmětem primárního sdělení by měla být informace obsahující druhové nebo alespoň rodové jméno hada, čas uštknutí a momentální klinický stav pacienta

- TC doporučí další postup, potřebná vyšetření ke stanovení diagnózy a vhodné zajištění pacienta; $v$ indikovaných prípadech při systémové intoxikaci nabídne hospitalizaci pacienta v TC

\section{Literatura}

1. Markland FS. Snake venoms and the hemostatic system. Toxicon 1998; 36(12): 1749-800.

2. White J. Snake venom and coagulopathy. Toxicon 2005; 45(8): 951-967. Dostupné z DOI: <http://dx.doi.org/10.1016/j. toxicon.2005.02.030>

3. Senise LV, Yamashita KM, Santoro ML. Bothrops jararaca envenomation: Pathogenesis of hemostatic disturbances and intravascular hemolysis. Exp Biol Med (Maywood) 2015; 240(11): 1528-1536. Dostupné z DOI: <http://dx.doi.org/10.1177/1535370215590818>.

4. Isbister GK, Williams V, Brown SG et al. Australian Snakebite Project Investigators. Clinically applicable laboratory end-points for treating snakebite coagulopathy. Pathology 2006; 38(6): 568-572.

5. Tanos PP, Isbister GK, Lalloo DG et al. A model for venom-induced consumptive coagulopathy in snake bite. Toxicon 2008; 52(7): 769-780. Dostupné z DOI: <http://dx.doi.org/10.1016/j.toxicon.2008.08.013>.

6. Warrell DA, Davidson NMcD, Greenwood BM et al. Poisoning by bites of the saw-scaled or carpet viper (Echis carinatus) in Nigeria. Q J Med 1977; 46(181): 33-62.

7. Maduwage K, Isbister GK. Current treatment for venom-induced consumption coagulopathy resulting from snakebite. PLoS Negl Trop Dis 2014; 8(10): e3220. Dostupné z DOI: <http://dx.doi.org/10.1371/ journal.pntd.0003220>.

\section{MUDr. Jiří Valenta $\square$ Jiri.Valenta@vfn.cz}

Toxinologické centrum, Kliniky anesteziologie, resuscitace a intenzivní medicíny 1 LF UK a VFN v Praze

www.karim-vfn.cz

Doručeno do redakce 1.2. 2018 